\title{
Exploring Employment Status and Education-Job Match among Engineering Graduates in Ethiopia: Policy Implications
}

\author{
Tamiru Jote
}

\begin{abstract}
The article explores the employment status and education-job match among engineering graduates in Ethiopia between the years 2009 and 20I3, and implications on the expansion of engineering programs. The findings reveal that engineering graduates have had a good employment status in the five years of the study, with an average employment rate of 80.3 percent. However, an increasing trend of graduate unemployment is observed. Substantial variations are observed among graduates of the various engineering disciplines and between men and women: civil engineers have better employment prospects, and the employment status of women is consistently lower. The findings also indicate that the education-job mismatch is both vertical and horizontal, and affects more than a third of the graduates (4I.5 percent). Thus, there is a need to refocus on improving the quality of engineering education, and the decision to expand engineering programs should be based on insightful higher education planning and labor market assessment.
\end{abstract}

Key words: University graduates, employment, engineering education, education-job match, labor market, Ethiopia.

Cet article explore la situation d'emploi et la concordance entre la formation et l'activité professionnelle des ingénieurs diplômés en Ethiopie entre 2009 et 20I3, ainsi que les implications sur l'expansion des cursus d'ingénierie. Les résultats montrent que les ingénieurs diplômés ont bénéficié d'une bonne situation d'emploi durant les cinq ans étudiés, avec en moyenne un taux d'emploi de 80.3 pour cent. On observe cependant une 
augmentation du taux de chômage parmi les diplômés. D’importantes variations peuvent être observées entre les diplômés des différentes disciplines de l'ingénierie et entre les hommes et les femmes : les ingénieurs civils ont de meilleures perspectives d'emploi, et la situation d'emploi des femmes est systématiquement moins bonne sur toutes les disciplines. Les résultats indiquent aussi que le manque d'alignement entre la formation et l'emploi est aussi bien vertical qu'horizontal, et touche plus d'un tiers des diplômés (4I.5 pour cent). Il est nécessaire de privilégier à nouveau l'amélioration de la qualité des formations d'ingénieurs. La décision d'augmenter le nombre des cursus ingénieur doit être faite sur la base d'une planification de l'enseignement supérieur et d'une évaluation du marché du travail.

\section{Introduction}

Ethiopia is currently engaged in expanding its higher education sector, with the main goal to develop highly qualified, motivated, and innovative human resource that can produce and transfer advanced and relevant knowledge for socioeconomic development and poverty reduction, with a view to becoming a middle income country by 2025 (Ministry of Education [MoE], 20I0). The crucial role of higher education institutions (HEIs) in solving developmental problems through the production of skilled labor has received serious consideration. HEIs are expected to become responsive to the demands of the labor market, in the context of an increasingly competitive, complex, and globalized knowledge economy.

Since I994, a succession of new policies have been designed and implemented, leading to major quantitative and qualitative changes in Ethiopian higher education. In I994, the Education and Training Policy was the first framework for system reform and transformation. The document stressed the importance of higher education for the development of the country. The first Higher Education Proclamation was issued in 2003, followed by a new version in 2009. The 650/2009 Higher Education Proclamation (HEP) currently functions as the legislative framework for the transformation of higher education (MoE, 2010).

According to the 650/2009 Proclamation, HEIs are expected to prepare knowledgeable, skilled, and attitudinally mature graduates, in sufficient numbers and with the required quality within relevant fields and disciplines, for the country to become internationally competitive. Moreover, HEIs are intended to promote and enhance research, with a focus on knowledge and technology transfer consistent with the country's priorities (MoE, 2OIO).

Two higher education councils (or organs) support the work of the ministry of education and higher education institutions: the Higher Education Relevance and Quality Agency (HERQA) and Education Strategic Centre 
(ESC). HERQA was established in 2003. It is an autonomous legal body with the task to evaluate the quality and relevance of all HEIs (MoE, 20IO). The main role of ESC is to contribute to the development of higher education policy and institutions by developing national strategies and long term plans, engaging in data collection and analysis, conducting research on policies, practices and results, acting as a resource center for reform, change, and development, and consulting on higher education development (MoE, 20IO).

In addition to the structural reforms, Ethiopia is currently engaged in expanding its higher education system. MoE data from 2013 indicate that undergraduate enrollment numbers increased from 310,702 students in $2008 / 09$ to 553,848 students in $2012 / 13$. The key outcomes of higher education are a balanced distribution of higher education opportunities throughout the country, through widened access, in particular in science and technology, and increased student learning, personal growth, and improved employability. In 2008, the Ministry of Education introduced a new intake policy at Ethiopian public HEIs, with emphasis on science and technology. The policy aims to increase the workforce in science and technology to facilitate the implementation of the country's agricultureled industrialization policy. The policy document emphasizes the need to expand the annual intake considerably, and to achieve a new distribution between professional and general academic programs, with a 70 percent share to science and technology and a 30 percent share to humanities and social sciences for the five-year period from $2008 / 2009$ to $2012 / 2013$. The distribution among fields of study is as follows: engineering and technology, 40 percent; natural and computational sciences, 20 percent; medicine and health sciences, 5 percent; agricultural sciences, 5 percent; business and economics, 20 percent; and social sciences and humanities, Io percent (MoE, 2008). In the year 20I2/2013, the ratio of the regular (official) undergraduate program in science and technology to all programs was 67:33 (MoE, 2OI3). This initiative clearly stipulates the weight given to science and technology in line with the development goal of the government.

The strategic development approach of the current government is to realize a fast track social and economic development underpinned by agriculture-led industrialization, with a priority focus on capacity development, small farm commercialization, export-led and import-substituting industrialization, and development of the physical infrastructure as well as of information and communication technologies (Ministry of Finance and Economic Development MoFED, 20I0). This will obviously require capacity building, particularly in engineering and technology. Understandably, the education sector in general, and higher education in particular, have started giving due emphasis to engineering education, as it stands out as a 
pillar for all endeavors in capacity building. This effort has been supported by the establishment of two science and technology universities and ten institutes of technology, and by strengthening the schools of engineering at twelve universities (Erhardt and Schultz, 2009).

Despite the upsurge of higher education institutions, enrollment rates, and graduate turnout, the issues of graduate unemployment and education-job mismatch pose challenges to many countries (Korka, 20I0; Bloom et al., 2006). Producing large numbers of graduates without careful attention to the specific needs of the labor market creates a gap between higher education and the world of work. As a result, a substantial number of graduates find the transition from study to work difficult, and securing a job commensurate with their aspirations challenging (Walters, 2002). In addition, even if the jobs do not require higher education credentials, employers tend to ask for higher education graduates, and graduates tend to accept (Korka, 2010).

Experience in most countries shows an inverse relationship between education and unemployment. Employment stability increases as workers become more educated. Though it is generally assumed that better education leads to increased employment opportunities, there are cases when the supply of workforce increases beyond the demand. In such cases, the employability of graduates may be affected, as higher education graduates are usually the group most responsive to a prospective rise in unemployment and underemployment (Livanos, 2009). Related to this, Akinyemi et al. (20I2) studied the labor market prospects of university graduates in Nigeria and concluded that graduate unemployment and underemployment were a new and growing phenomenon.

According to Teferra (20I5), "the expansion is rapid and consolidation is staggering, a once reluctantly tolerated predicament of unemployment for university graduates has surfaced with a vengeance." The considerable number of unemployed and underemployed graduates on the continent require organized actions. In spite of a number of studies examining graduates' employment situations and education-job match across the various fields of study in many countries (Walters, 2002; Zhaira, 20II; Olyomi and Adedeji, 20I2; Ponge, 20I3), these issues have not been adequately examined in Ethiopia.

Despite the initiatives and actions mentioned above, the employability of recently graduated engineers in Ethiopia has been a point of concern among stakeholders. Specifically, some employers are complaining about the competencies of recent graduates, and graduates themselves have reservations about the quality of the training they have received. Such important issues have not been adequately examined. This study takes the initiative to explore employment status and education-job match among engineer- 
ing graduates in Ethiopia between the years 2009 and 2013. The study is guided by the following three key questions:

I. What is the extent of employment/unemployment?

2. Is there a significant difference of employment/unemployment by field of study and gender? and

3. What is the extent of the education-job match?

The study consists of five sections. The first section introduces the problem and its context. The corresponding theoretical framework is dealt with in the second section, which highlights the relationship between education, labor market, and graduate employability. The third section presents the methodology employed. The fourth section analyzes the results according to the defined purpose of the study, and the last section provides conclusion and recommendations.

\section{Theoretical Framework}

There is a growing interest among academics and practitioners to systematically study the linkages between labor market and education. They are eager to search for the causes of growing disparities in labor market outcomes between workers with different levels and types of education. Consequently, policy concerns are raised about the relative costs and benefits of various levels and types of education, particularly higher education. A new focus on the roles of quantity and quality of human capital in the development process, moreover, has pushed further the need for critical scrutiny on education-labor market linkages (Fasih, 2008).

Vast research literature provides evidence on the value of investing in education to develop human capital that can meet the requirements of the labor market (Fasih, 2008; UNESCO, 2010). It is also evident that education directly affects success on the labor market. Specifically, higher education graduates can achieve a higher status and earn higher salaries (Walters, 2002). Given these contributions of education, especially at the higher education level, countries, communities, and individuals invest massively to raise their educational attainment. As a result, there has been rapid expansion of higher education, increases in enrollment rates, and graduate turnout.

The match or mismatch between the qualifications of higher education graduates and work requirements revolves around the relationships between the functions of universities, the requirements of the economy, and the production sector. One of the models (dependency) assumes a correspondence between graduates profiles and the jobs they fill that is matching, and responding to the demands of the workplace, whereas the other model, the relative autonomy model, proposes a dynamic regulation between labor supply and the production sector. Although it is difficult to 
forecast the future, the workforce available at any given time influences demand by stimulating it. Likewise, it is suggested that qualifications and skills cannot be assimilated just from formal undergraduate studies, due to other ways of learning such as work experience (Sala et al., 2007). A certain level of overeducation (the extent to which graduates are employed in nongraduate jobs) in the workforce may be positive in economic terms insofar as a greater abundance of qualifications may lead to better job possibilities by increasing the overall level of innovation and competitiveness (Lemistre, 2007; Sala et al., 2007).

On the one hand, some studies indicate the mismatch between the degree studied and the qualifications actually required of graduates for their job, and the negative impact of overeducation on motivation in the workplace. On the other hand, the empirical evidence shows a negative relationship between overeducation and innovative and extra-role behavior in the workplace, and also with regard to initiative in the personal development by graduates of their professional career (Agut, Peiro, and Grau, 2009).

The match between the employability of a growing number of university graduates and labor market demands and dynamics implies a transformation in the systems and institutions of higher education. The new educational model redefines the traditional role of the transmission of theoretical and practical knowledge in the different fields of study, and emphasizes applicability, action-orientation ability, and transferability of knowledge. The model advocates the introduction of quality assurance policies and procedures, the adaptation of university curricula to the requirements of the new economy and present-day labor markets, the development of competences, and a more active involvement of the learner.

\section{Methodology}

\subsection{Methods and data sources}

This study employed a descriptive survey research design. The data were collected from sample of engineering graduates and from archives. These data included output of Ethiopian higher education by field of study and sex, collected from the ministry of education, and annual abstracts of education statistics, representing the supply side scenarios. Demand side scenarios were obtained from labor force surveys, urban employment and unemployment surveys, labor market bulletins, and policy documents. These were collected from the archives of the Central Statistics Agency (CSA), the Ministry of Labor and Social Affairs (MoLSA), the Ministry of Civil Service (MCS), and the International Labor Organization (ILO) Ethiopia. 


\subsection{Sampling}

The study population included graduates during a period of five years (2009-2013) in selected fields of engineering. A survey addressing the link between higher education and employment has a limited scope if it is confined to the transition to employment and early career stages. The inclusion of several years of occupational experience provides a more complete picture, notably in two respects. First, the value of competencies acquired during the course of study can be analyzed appropriately only if several years of employment and work are taken into consideration. Higher education is not expected to prepare only for initial work tasks at the time of entry to employment. Second, the consequences of transitional experiences and of initial career decisions on later stages can be made visible if the survey also addresses employment and work at a time at which careers tend to stabilize.

All fields of engineering were not part of the population of this study. Civil engineering, electrical engineering, and mechanical engineering were purposely targeted, as these are recurring fields across Ethiopian higher education institutions. To calculate the number of employed/unemployed graduates in the past five years, basic questions I and 2, all graduates of engineering in the past five years were part of the population. To analyze the education-job match of graduates, basic questions 3 , the population did not include graduates in distance, extension, and summer programs, as the admission requirements of these programs were different from the generic ones. This sample included only those graduates who did not obtain any additional degree, diploma, or certificate subsequent to the one originally received in the years from 2009 to 2013 . Graduates who had obtained additional qualifications were excluded as they no longer belong to the original educational group. The total number of regular program graduates in the five cohorts (2009-2013) was 6,698. With a 5 percent margin of error, a design effect of 2 , and return rates of 90 percent, the sample size required for the survey was 378 using Yamane Taro's sample size calculation formula.

$$
n_{0}=\frac{N}{1+N e^{2}}=\frac{6698}{1+6698 x(0.05)^{2}}=378
$$

Where; $N=$ number of graduates, $e=$ margin of error and $n_{0}=$ initial sample size. 
The multistage sampling technique was employed to select sample graduates. First, the survey population was stratified into three fields of study i.e. civil engineering, electrical engineering, and mechanical engineering. Then, an independent systematic random sample of predetermined size was selected from each stratum, using stratified random sampling techniques. In this way, the researcher aimed to achieve a better identification of relevant characteristics, so that each group had the characteristics to be represented in the study sample.

The sample graduates were selected from 30 major engineering companies. The sample companies were selected based on:

I. Size of the company (small, medium, and large);

2. Activity field (construction, manufacturing, transport and communication, services, electricity, among others);

The target number of respondents (approximately ro percent from small, I5 percent from medium and 25 percent from large companies) depended on the size of the companies. With regard to the definition of the size of a company in Ethiopia, there is no standard to classify industrial size, even at the national level. However, the researcher tried to look into related works, both at the national and international levels, before fixing the range for this research. In their total quality management (TQM) implementation studies, Zelealem and Getachew (2002) classify companies based on the number of employees (small firms have 50 or less, while medium size firms have between 50 and I50). This research is also based itself on the number of employees: small firms have less than 50 employees, medium firms have 50 to 300 employees, whereas large firms have more than 300 employees. To select respondents from each company, a list of all eligible graduates was compiled to be used as a sampling frame. Finally, an independent sample was selected from each strata, using stratified random sampling based on the size of the companies and field of study.

\subsection{Instruments}

The data were gathered using questionnaires (graduate questionnaires) and document analysis.

The "graduate questionnaire" used for this survey was adapted from the standardized questionnaires developed by INCHER (International Centre for Higher Education Research). The questionnaire contained both closedand open-ended questions. The questions were designed to cover themes of activities during studies and after graduation in order to identify the education-job match among engineering graduates.

The other instrument used was official documents (archives). The relevant documents included policies, proclamations, statistical abstracts, labor force surveys, employment and unemployment surveys, labor market 
bulletins, and published materials related to higher education and the labor market in Ethiopia. These documents gave a basic overview of the employment/unemployment status of engineering graduates in the years $2009-2013$.

\subsection{Reliability test and procedure of data collection}

Prior to full-scale data collection, the questionnaire was piloted with a group of twelve graduates, four from each field of study. In order to improve the survey instruments, several cognitive interviews (think aloud) were conducted with the graduates. The validity of the instruments was consolidated by subjecting it to the thorough scrutiny of experts in relevant fields. To ensure the reliability of the survey instruments, test-retest reliability was considered. In order to check for the test-retest reliability, a survey instrument was tested by performing the same survey with the same respondent at two different moments in time. The closer the findings of the retested survey to the first test, the greater the reliability of the instrument. In order to measure for test-retest reliability in this research, I2 respondents among the graduates, four from each study program, were selected to pilot test the questionnaires. All of the respondents were contacted through their organizations to obtain their consent. Once they agreed, the questionnaires were distributed.

After all questionnaires were received and a delay of two weeks, new copies of the same questionnaires were sent to be filled again, and then collected. The Spearman correlation coefficient was used in order to measure the test-retest reliability. For the graduates, the Spearman correlation coefficient values on all questions were ranging from 0.62 to 0.87 and the entire values were significant at a 5 percent confidence interval. As such, the test-retest reliability for the questionnaire was established, as all of the correlation values were found to have a moderate-to-strong level of agreement.

The successful conduct of data collection and its quality was influenced by the experience of data enumerators and the procedures used to guide the data collection process. Well experienced data collectors were recruited and trained. In total three supervisors and eight data collectors were mobilized. Considering the relatively high concentration of potential employers in Addis Ababa, two supervisors and six data collectors were assigned to companies in the city. The remaining supervisor and two data collectors handled the regional data collection. Based on the list of selected major employers, the supervisors contacted them to identify the list of engineering graduates employed in the last five years; then the data enumerators traced the relevant graduates in the organizations. The data collectors submitted the filled questionnaires within a week. 


\subsection{Data analysis}

The data collected through the questionnaires were coded and entered into SPSS 2I statistical analysis software and cleaned for missing values, outliers, and duplicate cases. Then, a descriptive statistical analysis was conducted providing data in percentages, means, and standard deviations. Furthermore, ANOVA was used to test the statistical significance of opinion differences across the sample engineering study programs. Chi square tests were calculated and self-weighted to obtain the magnitude of differences between groups. The normality and heterogeneity of variances were examined to ensure that all assumptions were met to perform the statistical tests.

\subsection{Ethical considerations}

The data collection was performed after clearance guaranteed from the Department of Educational Planning and Management at Addis Ababa University. Informed consent was sought and obtained from all eligible respondents before distributing the questionnaire. All data collections were conducted in privacy.

\section{Results and Discussions}

On the basis of the individual characteristics reported by the respondents, this section presents an analysis of the patterns of their (un)employment status, with a view to determine the correlation between the output of higher education and the demands of the labor market. In addition, the section discusses the education-job match of the engineering graduates.

\subsection{Characteristics reported by the respondents}

Among a total of 6,698 regular program graduates from civil, electrical, and mechanical engineering between the years 2009 and 2013, 378 respondents were selected, using Yemano Taro's sample size determination formula. A total of 350 questionnaires were filled out and returned, a 92.5 percent return rate. 
Table 1. Respondents distribution by field of studies, cohort, gender and GPA

\begin{tabular}{|c|c|c|}
\hline Respondents characteristics & Frequency & $\begin{array}{l}\text { Proportion } \\
\text { percent) }\end{array}$ \\
\hline \multicolumn{3}{|l|}{ Field of studies } \\
\hline Civil engineering & 148 & 42.2 \\
\hline Electrical engineering & 130 & 37.2 \\
\hline Mechanical engineering & 72 & 20.6 \\
\hline \multicolumn{3}{|l|}{ Gender } \\
\hline Male & 280 & 80 \\
\hline Female & 70 & 20 \\
\hline \multicolumn{3}{|l|}{ Cohort } \\
\hline 2009 & 52 & 14.7 \\
\hline 2010 & 56 & 16.0 \\
\hline 2011 & 45 & 13.0 \\
\hline 2012 & 71 & 20.3 \\
\hline 2013 & 126 & 36.0 \\
\hline \multicolumn{3}{|l|}{ GPA } \\
\hline $3.75-4.0$ & 29 & 8.3 \\
\hline $3.5-3.74$ & 38 & 10.8 \\
\hline $3.0-3.49$ & 138 & 39.4 \\
\hline $2.75-2.99$ & 69 & 19.7 \\
\hline $2.5-2.74$ & 43 & 12.3 \\
\hline $2.0-2.49$ & 33 & 9.5 \\
\hline TOTAL & & 100.0 \\
\hline
\end{tabular}

As shown in the above table, the respondents included 42.2 percent graduates from civil engineering, 37.2 percent from electrical engineering, and 20.6 percent from mechanical engineering. The 2013 cohort had the largest proportion of respondents (36 percent), followed by cohorts 2012 (20.3 percent); 2010 (I6.0 percent); 2009 (I4.7 percent) and $20 \mathrm{II}$ (I3.0 percent). This clearly reflects an increasing trend in output of engineering graduates over the five years surveyed. The majority of the respondents, 58.5 percent, graduated with a GPA of 3.0 and above and only 9.5 percent of the graduates scored between 2.00 and 2.49 . 
Figure 1. Field of study and gender cross tabulation in percentages

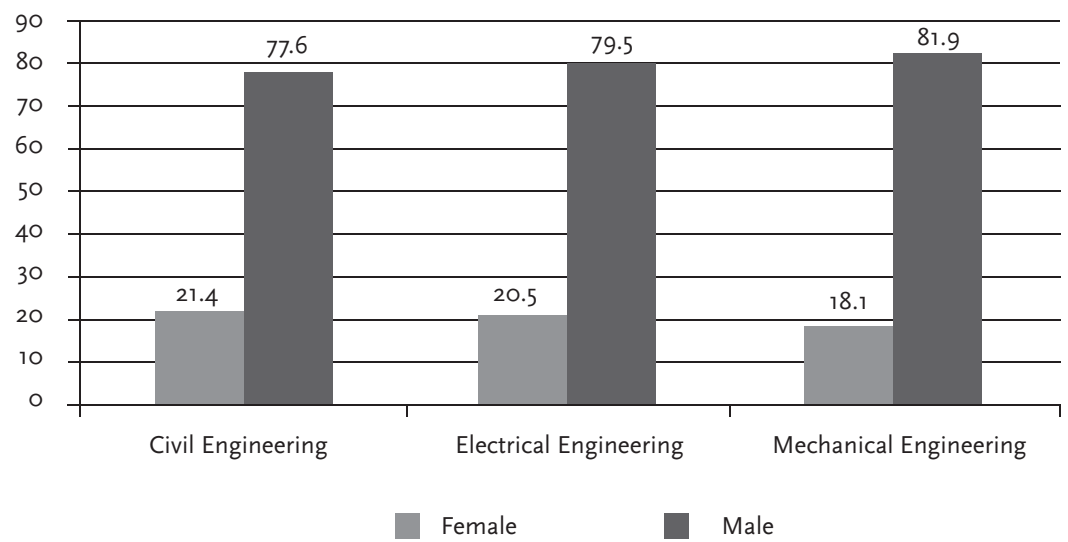

In all engineering programs, there are more men than women, in particular in mechanical engineering. These figures reflect the existing gender gap in Ethiopian higher education, where the admission rate of women in engineering, compared to men, is less than 30 percent.

\section{2. (Un)employment status of engineering graduates}

A look at the development of higher education intake in Ethiopia in general, and in engineering in particular, shows that recently the number of graduates has been rapidly increasing, and that engineering graduates occupy a stronger position in the labor market. Examining the (un)employment status of engineering graduates is helpful to inform educational planners, decision makers, and other stakeholders.

\subsubsection{Employment status of engineering graduates}

Like other African countries, Ethiopia is challenged with a fast growing population coupled with a developing economy. This scenario needs proper management and an efficient utilization of the workforce. The capacity of the economy to absorb the potential labor force needs to be monitored regularly, and appropriate educational and employment policies are crucial. The levels and trends of employment and unemployment rates of the country are widely used as overall indicators to evaluate the current performance of the economy. The objective of this study to analyze the employment status of engineering graduates is, therefore, essential to capture the current employment situation and help foresee future changes. It can also be an input for the assessment of the ministry of education's policy on the 70/30 mix of professional and academic subject areas at HEIs. 
Table 2. Employment trend per year and field of study, in percentages

\begin{tabular}{|l|l|l|l|l|l|c|}
\hline \multirow{2}{*}{ Study Program } & \multicolumn{3}{l}{ Year } & \multicolumn{2}{l|}{$\begin{array}{l}\text { Average } \\
\mathbf{2 0 0 9 / 2 0 1 3}\end{array}$} \\
\cline { 2 - 8 } & $\mathbf{2 0 0 9}$ & $\mathbf{2 0 1 0}$ & $\mathbf{2 0 1 1}$ & $\mathbf{2 0 1 2}$ & $\mathbf{2 0 1 3}$ & \\
\hline Civil engineering & 88.14 & 86.60 & 80.60 & 88.36 & 79.91 & 84.72 \\
\hline Electrical engineering & 74.65 & 66.56 & 65.43 & 87.03 & 79.49 & 74.63 \\
\hline Mechanical engineering & 77.25 & 83.97 & 75.15 & 81.85 & 85.48 & 80.74 \\
\hline Total & & & & 80.3 \\
\hline
\end{tabular}

Source: CSA Employment Unemployment Surveys, 2009-2013

The employment trend has varied for all graduates over the five-year period of the study. Though the employment trend was variable over the time period of the study, the average probability of being employed for engineering graduates stood at 80.3 percent. Relative to the overall labor force, they were better off in terms of access to employment. These good employment opportunities for engineering graduates may be attributed, in part, to the high economic growth recorded in the country over the past years. Growth has been driven by development in infrastructure and industry (among others metal, cement, and engineering; textile and garment; sugar and sugar-related products) attracting mainly engineering graduates. As the economy of a nation grows, the demand for high-skilled labor increases rapidly. This finding also supports the core of human capital theory, according to which education responds to industrial and economic growth (Walters, 2004).

In spite of healthy overall employment opportunities among engineering graduates, the extent to which employment outcomes can be attributed to gender differences is crucial. There are still considerable differences in gender enrollment, especially in engineering and applied sciences, with female enrollment of less than 30 percent in 2013 (MoE, 20I3). Women are less likely to work in high-skilled positions across all occupational sectors. Most are traditionally employed in lower level white collar occupations (Boyd, I990). 
Table 3. Employment status of engineering graduates by year, field of study, and sex

\begin{tabular}{|l|l|l|l|l|l|l|c|}
\hline Study Program & Sex & 2009 & 2010 & 2011 & 2012 & 2013 & $\begin{array}{l}\text { Average } \\
2009 / 2013\end{array}$ \\
\hline \multirow{2}{*}{ Civil engineering } & Male & 89.38 & 90.74 & 84.29 & 92.73 & 81.68 & 87.76 \\
\cline { 2 - 8 } & Female & 76.91 & 65.86 & 60.39 & 78.11 & 71.56 & 70.56 \\
\hline \multirow{2}{*}{ Electrical engineering } & Male & 81.65 & 74.49 & 76.21 & 84.83 & 83.17 & 80.07 \\
\cline { 2 - 8 } & Female & 46.44 & 26.61 & 31.38 & 100.00 & 65.52 & 53.99 \\
\hline \multirow{2}{*}{ Mechanical engineering } & Male & 76.97 & 82.82 & 87.38 & 82.59 & 79.59 & 81.87 \\
\cline { 2 - 8 } & Female & 83.69 & 92.43 & 12.45 & 72.46 & 82.67 & 68.74 \\
\hline \multirow{2}{*}{ Total } & Male & & & & 83.21 \\
\cline { 2 - 7 } & Female & \multicolumn{7}{|l}{} & & 64.43 \\
\hline
\end{tabular}

The above table reveals that male engineering graduates have a consistently better employment status than female colleagues. On average civil engineering female graduates (70.56 percent) have better employment opportunities, followed by mechanical (68.74 percent) and electrical engineering (53.99 percent) female graduates. Across all five cohorts, however, women have a lower employment status. This finding is consistent with other studies: Finnie (2000) found that the labor force participation rate of female higher education graduates is more variable than it is for their male counterparts, and that compared with men, women's employment status in the fields of engineering and applied sciences is looser.

\subsubsection{Unemployment status of engineering graduates}

"Unemployment rate" is used to describe the proportion of unemployed population in relation to the total labor force. The rate indicates the number of persons who are ready to participate in the production of goods and services, although they cannot get employment. The unemployment rate is computed as the percentage of the unemployed population over the total number of economically active population. 
Table 4. Unemployed engineering graduates per year and field of study in percentages

\begin{tabular}{|l|l|l|l|l|l|l|}
\hline Study Program & $\mathbf{2 0 0 9}$ & $\mathbf{2 0 1 0}$ & $\mathbf{2 0 1 1}$ & $\mathbf{2 0 1 2}$ & $\mathbf{2 0 1 3}$ & $\begin{array}{l}\text { Average } \\
\mathbf{2 0 0 9 / 2 0 1 3}\end{array}$ \\
\hline Civil engineering & 8.39 & 9.46 & 4.90 & 4.20 & 12.52 & 7.89 \\
\hline Electrical engineering & 20.01 & 23.20 & 17.89 & 4.37 & 14.73 & 16.04 \\
\hline Mechanical engineering & 10.77 & 9.75 & 16.82 & 4.72 & 14.14 & 11.24 \\
\hline Total & \multicolumn{7}{|r|}{} & & 11.72 \\
\hline
\end{tabular}

Source: CSA Employment Unemployment Surveys, 2009-2013

Figure 2. Unemployment trend of engineering graduates by field of study, 2009-2013

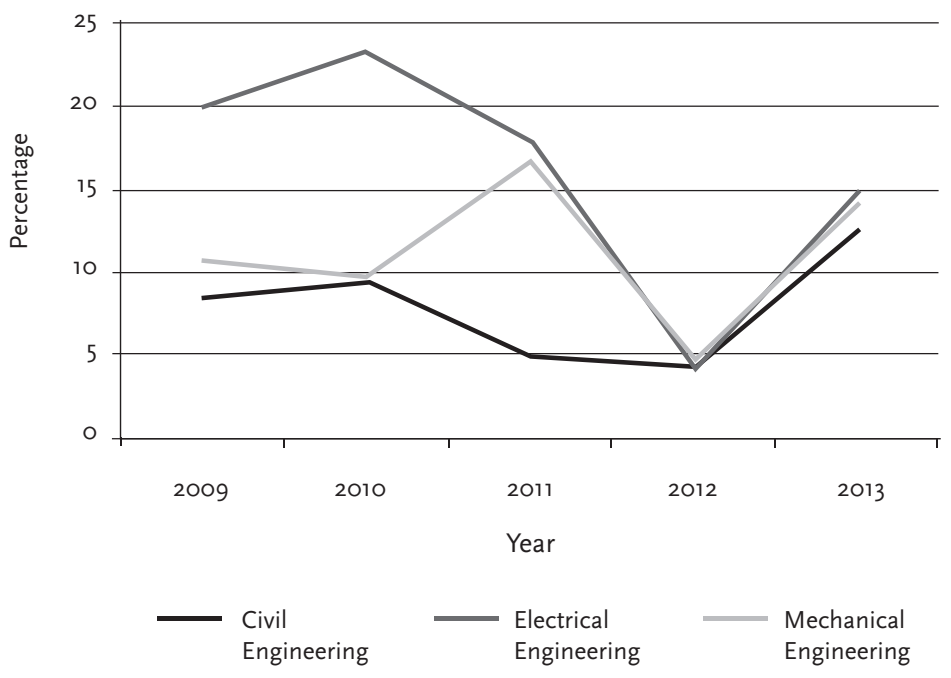

Source: CSA Employment Unemployment Surveys, 2009-2013

The above table and figure indicate that on average II.72 percent of engineering graduates were unemployed between the years 2009 and 2013 . By specific study program, on average electrical engineering graduates have the highest percentage of unemployment, I6.O percent, followed by mechanical engineering (II.24 percent) and civil engineering (7.89 percent) graduates. Civil engineering graduates generally have a consistently lower unemployment percentage than mechanical and electrical engineering 
graduates. Unemployment declined steadily for all graduates between 2009 and 2012, except for mechanical engineering graduates in the year 20II, and increased again slightly in 2013 .

Unemployment among engineering graduates also vary considerably by gender.

Table 5. Unemployment status of engineering graduates per year and sex

\begin{tabular}{|l|l|l|l|l|l|l|l|}
\hline Study Program & Sex & $\mathbf{2 0 0 9}$ & $\mathbf{2 0 1 0}$ & $\mathbf{2 0 1 1}$ & $\mathbf{2 0 1 2}$ & $\mathbf{2 0 1 3}$ & $\begin{array}{l}\text { Average } \\
\mathbf{2 0 0 9 / 2 0 1 3}\end{array}$ \\
\hline \multirow{2}{*}{ Civil engineering } & Male & 6.77 & 4.75 & 3.89 & 5.99 & 13.33 & 6.94 \\
\cline { 2 - 8 } & Female & 23.08 & 33.06 & 10.14 & $0.00^{\mathrm{I}}$ & 8.68 & 14.99 \\
\hline \multirow{2}{*}{$\begin{array}{l}\text { Electrical } \\
\text { engineering }\end{array}$} & Male & 11.65 & 19.04 & 19.63 & 5.12 & 12.04 & 13.55 \\
\cline { 2 - 8 } & Female & 53.55 & 41.89 & 12.33 & 0.00 & 25.01 & 26.55 \\
\hline $\begin{array}{l}\text { Mechanical } \\
\text { engineering }\end{array}$ & Male & 10.53 & 10.60 & 6.90 & 5.09 & 13.99 & 9.42 \\
\cline { 2 - 8 } & Female & 16.30 & $2.89^{2}$ & 67.66 & 0.00 & 17.82 & 20.93 \\
\hline
\end{tabular}

Source: CSA Employment Unemployment Surveys, 2009-2013

Women engineering graduates have a much higher average unemployment percentage than men. The highest average unemployment rate is among female engineering graduates with electrical engineering degrees (26.5 percent). Male civil engineering graduates, on the other hand, have very low unemployment rates (6.9 percent). Similarly, Allen (I999) found that female graduates of engineering have the worst employment records of all female university graduates. This finding may confirm the assertion that women are having difficulties breaking into male dominated work environments.

The fact that employment outcome differences between men and women can be explained, at least partially, by gender differences in higher education attendance, lends support to the human capital theory (Walters, 2002). However, the fact that differences still persist even between men and women with similar levels of education and field of study raises an interesting question. Labor market discrimination is one of the leading explanations. Another reasonable explanation is that women and men utilize their human capital differently. Men, for example, might devote more time and effort to select occupations that are directly related to their

\footnotetext{
10.00 indicates that there were no women graduates actively searching for jobs and considered unemployed. (Unemployed women may not be active in job search.)

2 This figure is surprising, and shows that the engineering labour market for women graduates in Ethiopia is unpredictable due to many reasons, which need further research.
} 
schooling, and this could be a major explanation for why men have a better employment status than women, even after controlling for level of schooling and field of study (Walters, 2002).

To sum up, the sample engineering graduates had good employment opportunities over the years under investigation: on average, 80.3 percent were employed. Graduate unemployment was relatively low, at iI.7 percent, compared with public perception about the extent of the problem. In general, a cursory glance at the trends in engineering graduate employment in Ethiopia indicate that the labor market, on the whole, accommodated most of the engineering graduates.

\subsection{Education-job match of engineering graduates}

Though getting employment for recent graduates is a virtue in itself, another important indicator of the performance of higher education institutions is the degree of appropriateness between the qualifications obtained by graduates and their job characteristics. All things considered, this is an indicator of the level of consolidation of the students' professional projects and of accomplishment of their professional expectations (Coronias et al., 2007). When there is a lack of coherence between the required and offered educational level and specialization for a given job, this situation is usually termed as education-job mismatch.

The European Centre for the Development of Vocational Training (Cedefop) has identified two major categories of education-job mismatch: a vertical mismatch and a horizontal one (Cedefop, 20I0). A vertical mismatch occurs when the level of education of an individual is not suitable for the job. A vertical mismatch can occur in two ways: overeducation or undereducation. Overeducation happens when an individual is recruited for a job which requires a lower level of education than that possessed by the individual. On the other hand, undereducation happens when an individual has a lower level of education than that expected for the job. The logical end result of a vertical mismatch is either the presence of overeducated workers who bring skills to their jobs in excess of the skills required for that job, or undereducated workers whose skills are inferior compared to those required for that particular job. According to Cedefop (20I0), both these situations may result in negative consequences for the job market. 
Table 6. Vertical education-job match of engineering graduates in percentages

\begin{tabular}{|l|l|l|l|l|l|}
\hline \multirow{2}{*}{ No } & Fitness of level of education to work & \multicolumn{2}{l}{ Study Program } & \multirow{2}{*}{ Total } \\
\cline { 3 - 5 } & & CE & EE & ME & \\
\hline 1 & Higher than bachelor degree & 14.3 & 9.2 & 16.9 & \multirow{2}{*}{12.9} \\
\hline 2 & Bachelor degree & 78.9 & 84.0 & 70.8 & 79.2 \\
\hline 3 & Non-degree program & 3.8 & 6.8 & 7.7 & 5.7 \\
\hline 4 & Lower level than tertiary education & 3.0 & 0.0 & 4.6 & 2.2 \\
\hline
\end{tabular}

Horizontal mismatch occurs when the type of education of an individual is inappropriate for the job, such as when a person does a job unrelated to his or her field of study (Robst, 2007). Horizontal mismatch in the case of graduate employment is worth studying. The analysis of the degree of match between jobs obtained by engineering graduates in the five years of the study, and their level of education (vertical match) and field of study (horizontal match) is depicted in tables 6 and 7 respectively.

With regard to the fitness between level of education and current work (vertical match), most graduates (79.2 percent) agree that a bachelor degree is the most appropriate level for their jobs. Only 7.9 percent state that their jobs could also be done by a non-degree holder or by someone with a lower education background than tertiary (overeducated). I2.9 percent graduates believe that the most fitting level of education for their jobs is higher than a bachelor degree (undereducated).

According to the primary data presented in the above table, vertical education-job mismatch (total of over- and undereducation) is 20.8 percent. This figure indicates that vertical mismatch, which has been considered as the major indicator of education-job mismatch, is substantial among engineering graduates in Ethiopia in the five years of the study, compared with some OECD countries. In these countries, on average Io-30 percent of the graduates are vertically mismatched (Allen and Van-der-Velden, 200I). Among the graduates, I2.9 percent are undereducated and 7.9 percent are overeducated, which is likely to be perceived as serious from the education providers' point of view. A high percentage of under- and overeducated graduates shows the inappropriateness of the higher education programs to fulfill the needs of the work market.

By study program, electrical engineering (84 percent), civil engineering (78.9 percent), and mechanical engineering (70.8 percent) graduates believe that the bachelor degree is the most appropriate education for their current jobs. Mechanical engineering (I6.9 percent) and civil engineering (I4.3 percent) graduates state that a higher degree than the bachelor is the most appropriate for their work (in other words, they perceive themselves as undereducated). The ANOVA results indicated no statistically significant 
difference in the fitness of level of education to current job (mean=9.45, $\mathrm{df}=6, \mathrm{P}>0.05)$. Despite the percentage difference there was no significant difference among graduates from different engineering programs between their level of education and their current job requirements.

Table 7. Horizontal education-job match of engineering graduates in percentages

\begin{tabular}{|c|c|c|c|c|c|}
\hline \multirow[t]{2}{*}{ No } & \multirow[t]{2}{*}{ Fitness of study program to work requirements } & \multicolumn{3}{|c|}{ Study Program } & \multirow[t]{2}{*}{ Total } \\
\hline & & CE & $\mathrm{EE}$ & $\mathrm{ME}$ & \\
\hline 1 & $\begin{array}{l}\text { My field of study is the only possible/by far the best } \\
\text { field }\end{array}$ & 67.2 & 54.2 & 59.2 & 60.6 \\
\hline 2 & $\begin{array}{l}\text { Other fields of study could also prepare for this kind } \\
\text { of job }\end{array}$ & 25.4 & 28.3 & 28.2 & 27.1 \\
\hline 3 & $\begin{array}{l}\text { Other fields of study could work better in this kind } \\
\text { of job }\end{array}$ & 0.7 & 6.7 & 5.6 & 4.0 \\
\hline 4 & The field of study does not matter very much & 5.2 & 6.7 & 2.8 & 5.2 \\
\hline 5 & $\begin{array}{l}\text { Higher education studies are not at all related to my } \\
\text { area of work }\end{array}$ & 1.5 & 4.1 & 4.2 & 3.1 \\
\hline
\end{tabular}

When the graduates were asked if their current work was related to their studies or not (horizontal mismatch), 60.6 percent stated that their fields of study were the only possible, or by far the best; for 27.I percent, other fields of study could also prepare for the job; 5.2 percent stated that the field of study did not really matter much. Altogether, I2.3 percent of the graduates were engaged in jobs which were not relevant to their field of study or expertise. Allen and Van-der-Velden (200I) reveal that, on average, 8 percent of graduates are horizontally mismatched among some OECD countries. The higher percentage in Ethiopia for engineering graduates indicates a high degree of horizontal education-job mismatch.

Regarding study programs, most civil engineering (67.2 percent) and mechanical engineering (59.2 percent) graduates stated that their fields of study were the best for their current work, compared with 54.2 percent electrical engineering graduates. A significant proportion of electrical engineering (28.3 percent) and mechanical engineering (28.2 percent) graduates felt that other fields of study could also prepare for this kind of job. The ANOVA result indicated no statistically significant difference in fitness of the study program to their current job (Mean=II. 32, $d f=8$, $\mathrm{P}>0.05)$.

To evaluate the overall education-job match of engineering graduates in Ethiopia in the five years of the study, the survey formulated two supplementary questions relating to their current job: "Is your current work related to the field of study?" and: "What is the most appropriate level of 
degree for your current employment and work?" Table 8 shows the results obtained according to field of study for each of the four categories, resulting from the combination of these two questions:

Table 8. Education-job match of engineering graduates

\begin{tabular}{|c|c|c|c|}
\hline No & Education-Job match & Study Program & Percent (\%) \\
\hline \multirow[t]{4}{*}{1} & \multirow{4}{*}{$\begin{array}{l}\text { Study program and level of education matched with } \\
\text { a job }\end{array}$} & CE & 53.4 \\
\hline & & $\mathrm{EE}$ & $45 \cdot 7$ \\
\hline & & $\mathrm{ME}$ & 39.1 \\
\hline & & Total & 47.5 \\
\hline \multirow[t]{4}{*}{2} & \multirow{4}{*}{$\begin{array}{l}\text { The study program matched with a job but the level } \\
\text { of education was unrelated }\end{array}$} & CE & 10.7 \\
\hline & & $\mathrm{EE}$ & 6.0 \\
\hline & & $\mathrm{ME}$ & 11.6 \\
\hline & & Total & 9.2 \\
\hline \multirow[t]{4}{*}{3} & \multirow{4}{*}{$\begin{array}{l}\text { Study program did not match with the job, but the } \\
\text { level of education related }\end{array}$} & CE & 0.0 \\
\hline & & $\mathrm{EE}$ & 4.3 \\
\hline & & $\mathrm{ME}$ & 1.4 \\
\hline & & Total & 1.9 \\
\hline \multirow[t]{4}{*}{4} & \multirow{4}{*}{$\begin{array}{l}\text { The study program and the level of education did } \\
\text { not match with the current job. }\end{array}$} & CE & 35.9 \\
\hline & & $\mathrm{EE}$ & 44.0 \\
\hline & & $\mathrm{ME}$ & 47.8 \\
\hline & & Total & 41.5 \\
\hline
\end{tabular}

As shown on table 8, 47.5 percent of graduates expressed that their higher education training matched with their current work in terms of field of study and level of education. On the other hand, a significant proportion of the graduates (4I.5 percent) indicated that there was mismatch between their higher education training and current job in both study program and level of education. This finding was not different among graduates of civil, electrical, and mechanical engineering graduates. The ANOVA result indicated no statistically significant difference in opinion of different study program graduates in terms of education-job match (mean=4.3, $\mathrm{df}=2, \mathrm{P}>0.05$ ). When a person is educationally mismatched, he or she will be unable to utilize the skills acquired through learning and also unable to gain real output from the investment made on the education (Green and McIntosh, 2007).

Some authors believe that education-job mismatch happens primarily due to the problems of educational structure and quality and the content 
of the educational programs, particularly when higher education has failed to provide the required skills, aptitudes, and job orientation for the graduate workforce (McGuinness, 2006). This indicates that the education-job mismatch is an issue of the supply side of labor. But Greene et al. (2009) reveal that higher education nowadays is more geared toward skills development. Especially, higher education is now seriously engaging in changing the teaching-learning package, in line with current requirements of more challenging business environments. Accordingly, during the past decade, student-centered teaching methods have been practiced instead of teacher-centered methods. This allows students to take greater initiative for self-learning and develop their skills through investigation, analysis, and various project work involving team or group work.

The above discussions indicate that authorities have taken steps to reduce the supply side of the education-job mismatch during the past decade. However, even after these actions, some issues still persist. Scholars have identified that the education-job mismatch is not always a result of inefficiencies on the supply side. There are issues on the demand side as well. For instance, if the number of graduates on the job market exceeds the demand, if the economy is unable to produce enough job opportunities to absorb the supply of graduates, it will be difficult for graduates to find a suitable job. Educated youth must either wait until they find a job matching their qualifications, or accept any job, whether it matches or not (Cedefop, 2010).

It is possible to claim that there definitely is an education-job mismatch among engineering graduates. Overall, 4I.5 percent of engineering graduates are engaged in jobs which are not related to their field of study and level of education. This is identified as a serious problem in the engineering labor market in Ethiopia between the years 2009 and 2013. It implies that the higher education system does not adequately comply with job market requirements.

\section{Conclusions and Recommendations}

This survey demonstrates that the labor market accommodated most engineering graduates in Ethiopia in the years 2009-20I3. It also confirms that concerns that engineering enrollments have expanded too rapidly were not based on empirical evidence. The labor market in Ethiopia has room for more engineering graduates. But this does not mean that a further expansion should not be made cautiously. As indicated above, there is an increasing trend of unemployment among engineering graduates. A further expansion should be based on insightful higher education planning and labor market assessment.

This study reveals further that across all the five cohorts, women have 
a lower employment status than men. Some gender differences can be attributed to gender differences in access to higher education. However, the fact that differences still persist between women and men in similar fields of study, and with similar levels of education, raises a question. It is known that employment policy in Ethiopia encourages women, but not sufficiently. Though theoretical explanations abound, this issue has not been thoroughly examined. Further studies should be conducted to adequately address this issue.

In spite of the positive employment status of engineering graduates, for about one third of them there is an education-job mismatch. This mismatch represents an inefficient use of human resources and a loss for society. The incidence of overeducation does not mean that the level of education should be lowered: it rather suggests the need to improve the quality of engineering education. The findings also reveal the necessity of reforms in human resource development and labor market institutions in Ethiopia. The phenomenon of education-job mismatch highlights the poor coordination among stakeholders both on the demand and on the supply sides. Closer coordination is a prerequisite to understand these issues better and formulate appropriate policies.

Matching skills and jobs is a high priority policy concern. Skills mismatches occur when graduates have either fewer, or higher skills than jobs require. Some mismatch is inevitable, as the labor market involves complex decisions. But it is crucial to ensure that skills taught at higher education institutions are relevant for the world of work; that they are maintained and further improved during the working life of the graduates; and that they are recognized and used in the labor market.

\section{References}

Akinyemi, S., Ofem Igot, B., \& Ikuenomore, S. (20I2). Graduate turnout and graduate employment in Nigeria. Lagos: Lagos State University.

Allen, J., \& Van der Velden, R. (200I). Educational mismatches vs skill mismatches: Effects

on wage, job satisfaction and on the job search. Oxford Economic Papers, $53,434-452$.

Bloom, D., Canning, D., \& Kevin C. (2006). Higher education and economic development. Washington, DC: Oxford University Press.

Boateng, K. \& Ofori Sarpong, E. (2002). An analytical study of the labor market for tertiary graduates in Ghana. Accra: World Bank Publications.

Boateng, K. (I998). Quality jobs or mass employment? A study of some impacts of structural adjustment in the Ghanian labour market. Economic Research Consortium, 80,

Boyd, M. (I990.) Sex Differences in Occupational Skill: Canada I96I-I986. 
Canadian Review of Sociology and Anthropology, 29 (3): 285-3I5.

Cedefop, (2010). The skill matching challenge: Analyzing skill mismatch and policy applications. Luxembourg: Publications Office of the European Union.

Coronias, E., Carme, S. \& Esperanca, V. (2007). The match between university education and

graduate labour market outcomes (Education-Job Match). An analysis of three graduates cohorts in Catalonia. Catalunya: Catalunya University. Retrieved December I, 2013 from www.aqu.cat

CSA (20I4). Statistical report on urban employment, unemployment survey. Statistical Bulletin.

----- (20I2). Statistical report on urban employment, unemployment survey. Statistical Bulletin.

------(20II). Statistical report on urban employment, unemployment survey. Statistical Bulletin.

------ (20IO). Statistical report on urban employment, unemployment survey. Statistical Bulletin.

(2009). Statistical report on urban employment, unemployment survey. Statistical Bulletin.

Fasih, T. (2008). Linking education policy to labor market outcomes. Washington DC: World Bank

Finnie, R. (2000). Holding their own: Employment and earnings of post secondary graduates. Education Quarterly Review,7(I)

Korka, M. (20I0). Graduate labour market mismatches. (Retrieved December I, 2014 from www.ceeol.com)

Livanos, L. (2009). The relationship between higher education and labour market in Greece:

The weakest link? MPRA Paper No.16239. Coventry: Warwick University Press. (Retrieved October I2, 20I2 from www.mpra.ub.uni-muenchen. de)

Livingstone, D. (I998). The education-job gap: Underemployment and economic democracy. Colorado: West View Press

McGuinness, S. (2006). Over education in the labor market. Journal of Economic Surveys, 20 (3)

MoE (2013) Education statistics annual abstract 2005 E.C. (2012/13). Addis Ababa: EMIS, Planning and Resource Mobilization Directorate

----- ( 20I2). Education statistics annual abstract. 2004 E.C./2OII-20I2. Addis Ababa: EMIS

------(20I0). Education statistics annual abstract. 200IE.C./2008-2009. Addis Ababa: EMIS

(20I0). Education sector development program IV (ESDP IV). 2003 E.C. -2007 E.C./2010/11-2014/15. Program action plan. Addis Ababa: FDRE. 
(2008). Annual intake and enrollment growth and professional and program mix of

Ethiopian public higher education: Strategy and conversion plan, 2008/o92011/12. Addis Ababa: FDRE

Oluyomi, S. \& Adedeji, S. (20I2). Skill mismatch among university graduates in the Nigeria labour market. Nigeria: David Publishing.

Ponge, A (20I3). Graduate unemployment and un employability in Kenya: Transforming

university education to cope with market demands and the lessons for Africa.International Journal of Social Science Tomorrow, 2(3), Retrieved March 2, 20I3 from www.ijsst.com

Robst, J. (2007). Education and job match: The relatedness of college major and work. Economics of Education Review, 26(4)

Sala,etal. (2007) "The transition from higher education to employment inEurope: the analysis of the time to obtain the first job”. A: Higher Education, 54, pp.333-360.

Schomburg, H. (2003). Handbook for graduate tracer studies. University of Kassel: Germany. (Retrieved February 7, 2013 from http://www.qtafi. de/handbook_v2.pdf)

Teferra, D. (2015). Africa's troika conundrums: Expansion, consolidation and un

(der)employment? International Higher Education:AQuarterly Publication, 80, 18. (Retrieved April I5, 20I5 from www.ejournals.bc.edu/ojs/index. php/ihe/articles)

Teshome W. (I990). The Development of higher education and social change. The Ethiopian experience. East Lansing: Michigan State University Press.

UNESCO (20I0). Engineering: Issues, challenges and opportunities for development. Paris: UNESCO Publishing.

Walters, D. (2002). The relationship between postsecondary education and labour market

outcomes: Comparing graduates over a four cohort period. An open access Dissertation. (Retrieved October 4, 2012 from www.digitalcommons. mcmaster.ca)

Walters D. (2004). The relationship between post secondary education and skill. Comparing

credentialism with human capital theory. The Canadian Journal of Higher Education, 115(2).Retrieved May 2, 20I4 from www.ojs.library.ubc.ca

World Bank. (2003). Higher education development for Ethiopia: Pursuing the vision. Washington DC: World Bank

Zelealem T. , Getachew H. (2002) “Total quality management and the planning behavior of SMEs in developing economies”, The TQM 
Magazine, I4, pp.I8I-I9I

Zhaira, A. (20II). Employment of the graduate labour force and employers Needs:

Components of quality management in higher education in Romania. A dissertation. (Retrieved October 26, 20I3 from http://doctorat.ubbcluj.ro/ sustinerea_publica/rezumate/20II/management/Zaharie_Monica_ EN.pdf 